\title{
THE LAW OF NATURE IN STATE AND FED- ERAL JUDICIAL DECISIONS
}

\section{I}

The notion that there is a law higher and better and more in accord with justice than positive law we are told has paralleled the existence of the law itself. ${ }^{1}$ An appeal to reason or to the sense of mankind as to what is just and right and the insistence upon what ought to be law as binding because of its intrinsic reasonableness, are declared to be among the strongest liberalizing forces in legal history. ${ }^{2}$ This appeal to reason which commonly goes under the designation-the law of nature or law of reasonhas had an eventful history since the formulation of the notion by the Greeks and the Romans.

Natural law, a law to which legislation may or may not conform, is a conception which is constantly taking new form. It may be described as the recurrence in the evolution of justice of ideas of right in accordance with reason, ideas which are frequently regarded as superior to positive law. The concept is one which is often held to belong more properly to ethics, to philosophy or to politics; but current usage, particularly in continental European countries, terms it law. ${ }^{3}$

${ }^{2}$ Berolzheimer, The World's Legal Philosophies (Trans. by Rachel Szold Jastrow), Int., p. XII. "It is an ancient, never-ending dream of mankind that there is a peculiar, rigid and unchangeable law. This law is thought to be a law of reason. What is agreeable to the reason is supposed on that account to be law, and necessary for all times and places." Windscheid, Rectoral Address, p. 7, quoted in Gareis, Introduction to the Science of Law (Trans. by A. Kocourek), p. I9. See also Del Vecchio, Formal Bases of Law (Trans. by John Lisle), pp. 324-335 on "Natural Law as the Goal of Historical Development."

${ }^{2}$ Pound, Scope and Purpose of Sociological Jurisprudence, 24 Harvard Law Review, 608 .

${ }^{3}$ Ahrens, Cours de droit naturel ou de philosophe du droit, gives a brief survey of the growth of the natural law concept. Natural law or the philosophy of law is defined as "the science which presents the first principles of right discovered by reason and founded in the nature of man." Sth ed., p. I. Consult also Bergbohm, Jurisprudenz und Rechtsphilosophie, Vol. I, Part I, "Das Naturrecht der Gegenwart"; Jellinek, Allegemeine Staatslehre, pp. 314-323; Stammler, Wirthschaft und Recht, pp. I69-I88 (the latter denies the existence of natural law); Charmont, La senaissance du droit naturel. 
That there is "besides the reason which guides us in fixing the letter of the law, a larger reason which informs the spirit of the law" and which is in last resort the ultimate justification for the law itself is a pervasive principle the significance of which has not at times been fully appreciated. Natural law, defined by Grotius, "right reason as it guides men in the ultimate determination of right and wrong," is today as it has been in the past one of the important concepts in the realms of law, government and ethics. In the judicial decisions of the United States are to be found some notable applications of this concept, a survey of which is the purpose of this article. To understand and to better appreciate the modern use of the doctrine it is necessary to give a short account of the significant steps in the development of this far-reaching legal principle.

The Laze of Nature in Ancient and Mediaeval Times. The historical setting of the law of nature cannot be presented within the compass of a brief article. Moreover, the subject has been adequately treated in recent legal literature $e^{4}$ and for the present purpose a brief summary of some significant historical facts will suffice. The idea of a law of nature-permanent and universal on which law is based-was familiar to the Greeks, particularly Aristotle and Demosthenes. ${ }^{5}$ The Greek concept developed under Stoic influence into the guiding principle of reason which was held to be immanent in the universe and of which natural law was an expression. Among the philosophers Cicero was the great advocate of the Stoic philosophy of natural law. But of greater importance is the fact that the idea gained acceptance and received the approval of the jurists Paul and Gaius, and through them it was embodied among the principles of the great Corpus Juris. ${ }^{6}$ This law was regarded as the substance of the precepts

\footnotetext{
-Salmond, The Law of Nature, Ir Law Q. Rev. I2I; Pollock, Expansion of the Common Law, and Journal of the Society of Comparative Legislation, Vol. II, I900; Bryce, Studies in History and Jurisprudence, Vol. II, Essay, The Law of Nature. See also references on preceding page.

${ }^{5}$ Salmond, op. cit., pp. 123, ff. Cf. Rhet. I, Io and I3, wherein Aristotle refers to law that is universal "which is conformable merely to dictates of nature"; cf. Ahrens, Philosophie du droit dans l'antiquité, p. 296.

${ }^{6}$ Wardship is characterized by Gaius as an institution based on natural reason and a similar basis for leases is suggested by Paul. Cf. Gaius I, 189. Inst. $I, 20,6$. Phrases referring to the law of nature and of reason in Roman Law are:
} 
approved by "the common sense of all nations as embodying what was practically useful and convenient."

In the Middle Ages the law of nature and of reason which held such an important place in the Stoic philosophy of the later Roman Empire was gradually absorbed by the church and was eventually given definite and specific application in the canon law courts. To secure additional sanction from Aristotle, Cicero and Justinian for the civil jurisdiction of the clergy, it became advantageous to identify the law of nature with the law of God and to apply the principle in the application of law to concrete cases. Natural law came to be regarded as law in its fullest sense; it possessed the same imperative elements as legislative enactments. ${ }^{3}$ The law of nature came to be differentiated from ordinary statutes. All sovereigns were subject to this natural law which set limitations "to the exercise of every kind of human authority and the enactment of all positive law."

In the hands of Grotius and his successors the law of nature took the form of a rather well-defined code relative to such matters as reverence for God, family virtues, love of country, and the rights of liberty and property. Natural law in its pure form was to Grotius equivalent to the dictates of right reason, and as such, absolutely immutable, subject to change not even by God

ius commune omnium hominum-Gaius Inst. I, I; Dif. I. I, 9.

ius quod naturalis ratio constituit-Gaius Inst. $I, I$; also the famous phrase-aequum et bonum, aequitas; cited among others in the essay by Bryce, op. cit., p. 578 .

${ }^{7}$ Bryce, Essay on The Law of Nature, p. 578; Pollock, The History of the Law of Nature, Journal of the Society of Comparative Legislation, Vol. II, 1900; Salmond, pp. 128, ff. Gareis, Introduction to the Science of Law, p. I8. Cf. my volume, The American Doctrine of Judicial Supremacy, pp. I8, ff, and 289 . A portion of the historical part of this article follows with certain modifications the account given in the above volume.

${ }^{8}$ Dunning, Political Theories, Ancient and Mediaeval, p. 2II; Bryce, p. 597; Pound, Common Law and Legislation, 21 Harvard Law Review, 390; an able advocate of the "lex naturalis" was Thomas Aquinas, see Berolzheimer, op. cit., p. 98; "A civil statute that contravenes natural justice," affirms the mediaeval jurist Suarez, "is ipso facto void, for in the hierarchy of the laws the precepts of nature are higher both in source and in effect than those of any merely human power," Suarez, III, xii, 4; also Salmond, I3I, ff.

'Dunning, Political Theories, Ancient and Mediaeval, p. 28I; Ahrens, Sec. $4 \mathrm{r}$, p. $30 \mathrm{~S}$. 
himself. ${ }^{10}$ The law of nature by its very definition was a rule of life discoverable by human reason apart from any special revelation or the decision of any particular authority. Often it was equivalent to "a pretty frank appeal to expediency."11

Law of Nature in English Law. At an early day in England the law merchant was declared to be "a part of the law of nature and nations" and as such universal, and the king's judges in the absence of other authority were accorded the privilege of a "resort to the law of nature which is the ground of all laws."12 Following the mediaeval practice it was announced in 1563 that the law of nature rendered any custom or statute in conflict therewith void. In the seventeenth century the Court of King's Bench held that the law of nature was implied in "the law of the land" as used in Magna Charta. ${ }^{13}$ With the advent of the dogma of a presocial state of nature and the possession by the individual of natural rights of superior sanctity, the conception of a law of nature acquired a new meaning. Locke, the apologist for revolution in England, declared the law of nature to be "a determining body of rules for the conduct of men in their natural condition," embodying such fundamental matters as the right to life, liberty and property. ${ }^{14}$ The law of nature was regarded as an outgrowth of a state of nature which Locke used as a postulate and which Rousseau rendered a popular concept of the eighteenth century political philosophy. ${ }^{15}$

\footnotetext{
${ }^{10}$ Ibid., p. I65; Grotius is credited with the conception of a "primitive and natural jurisprudence founded on reason itself, the source of every other jurisprudence," Miraglia, Comparative Legal Philosophy (Trans. by John Lisle), p. 22; see also Berolzheimer, op. cir., p. II5; Salmond, p. I35.

11 That the philosophy of law and natural law were combined in ancient and mediaeval times is the contention of Berolzheimer, World's Legal Philosophies, p. 6; "In the Middle Ages, natural law protected the nations against the caprice of princes and papal power, defended German from Roman law, and upheld the demands of what was reasonable in the face of what became historical," Kohler, Philosophy of Law (Trans. by A. Albrecht), p. 6 .

${ }^{12}$ Mcllwain, High Court of Parliament, p. 72; Bryce, Essay, p. 600, Pound, 2I Harvard Law Review, 39r.

${ }^{13}$ Baggs Case, II Coke, 99 a.

14 Treatises of Government, II, sec. 87, p. I23.

${ }^{15}$ For a criticism of natural law as defined and used by Hobbes, Locke and Rousseau, see Kohler, Philosophy of Law, p. 25; for comments on natural law by Kant, cf. Salmond, pp. 136, I37.
} 
According to Sir Frederick Pollock, the real link between the mediaeval doctrine of the law of nature and the principles of the common law is the words "reason" and "reasonableness." Owing to the common lawyers' contempt for the canon law it became customary to speak of reason in preference to the law of nature. Thus from the natural law of ancient and mediaeval times he finds developed the reasonable man of English and American law. It is particularly necessary to note that nature and reason are practically interchangeable terms in the early development of the law of nature and that the term nature on account of its canon law association was gradually dropped and reason was used in its place by the English lawyers. As a consequence, reason, reasonableness or natural justice, outgrowths of the law of nature, have been clearly recognized in English law although the terminology used has tended to conceal the fact.16 Some of the evidences of the influence of natural law in the development of various branches of the modern law of England are thus summarized by Pollock:- ${ }^{17}$

Through Grotius international law was based squarely on the law of nature. The Grotian theory found acceptance in the famous opinion of Lord Mansfield in which he characterized the law of nations as "founded upon justice, equity, convenience, and the reason of the thing confirmed by long usage." The principle of Lord Mansfield was accepted by Blackstone who, in defining the law merchant, refers to certain legal consequences arising "from natural reason and the just construction of the law." The whole modern doctrine of what we now call quasi-contract rests on an application of principles derived from the law of nature.

The test of a reasonable man's conduct governs the modern law of negligence in England and America. Since the Middle Ages the law of nature, or of reason, has been "a principal or influential factor in developing the following branches of jurisprudence-equity, the law merchant, the law of nations, the general application, within the sphere of municipal law, of the principles of natural justice and reasonableness, and the body of rules for the choice of law and jurisdiction, and the application

${ }^{20}$ Pollock, Journal of Society of Comp. Leg., I900, p. 4I8.

${ }^{17}$ Expansion of the Common Law, Essay on The Law of Reason, pp. 107, ff. Cf. the common law doctrine that courts are to mold statutes "according to reason and convenience to the best use," Chitty's note to I Bl. Comm. 87 . 
of foreign law, which sum up under the head of conflict of laws or private international law."18

Natural justice, or the reason of the thing, which the common law recognized and applied was a direct outgrowth of the law of nature which the Romans identified with jus gentium and the mediaeval canon lawyers adopted as being divine law revealed through man's natural reason. The effect of reasonable practice, commercial reason and common sense of mankind in their influence on modern law Pollock thinks can scarcely be estimated. It is "hardly too much to say that it is the life of the modern common law."19

The law of nature as a basis for principles that are fundamental and unalterable developed in the eighteenth century into the familiar natural rights doctrine of English and French political thought. The most familiar presentation of the natural law concept is to be found in Blackstone's Commentaries, where the sacredness of the higher law is presented as follows:

Man, considered as a creature, must necessarily be subject to the laws of his Creator. . . . This will of his maker is called the law of nature. . . This law of nature, being coeval with mankind, and dictated by God himself, is of course superior in obligation to any other. It is binding over all the globe, in all countries, and at all times; no hưman laws are of any validity, if contrary to this; and such of them as are valid derive all their force and all their authority, mediately and immediately, from this original. ${ }^{20}$

To Blackstone the three absolute rights which proceed from the law of nature are the right of personal security, the right of personal liberty and the right of private property. ${ }^{21}$ Blackstone,

${ }^{18}$ Pollock, op. cit., p. xI3.

${ }^{19}$ For a different interpretation of the influence of natural law, consult Kohler, Philosophy of Law, pp. 6, 25, 350, ff.; Salmond, p. I42.

${ }^{20}$ Comm. I, pp. 4I-43.

${ }^{21}$ "These therefore, were formerly either by inheritance or purchase, the rights of all mankind; but, in most other countries of the world being now more less debased and destroyed, they at present may be said to remain in a peculiar and emphatical manner, the rights of the people of England. And these may be reduced to three principal or primary articles; the right of personal security, the right of personal liberty, and the right of private property, because, as there is no other known method of compulsion or abridging man's natural free will, but by an infringement or diminution of one or other of these important rights, 
however, places these precepts in the realm of moral restraints by admitting that no authority can prevent Parliament from enacting laws contrary thereto. ${ }^{22}$ It remained for the courts of the United States to give a definite legal sanctity to the doctrine of natural rights.

II

IAW OF NATURE IN THE PUBLIC LAW OF THE UNITED STATES

The influence of the notion of an overruling law of nature is apparent at an early period in the United States. Before the revolutionary leaders had made the doctrine of natural rights popular, George Mason in a Virginia case argued that "the laws of nature are the laws of God; whose authority can be superseded by no power on earth. A legislature must not obstruct our obedience to him from whose punishment they cannot protect us. All human constitutions which contradict his laws we are in conscience bound to disobey." ${ }^{23}$ Bonham's Case ${ }^{2 t}$ and Calvin's Case $^{25}$ were cited as precedents for declaring acts contrary to natural right and justice. Basing his judgment on this doctrine, Magistrate Symonds of Connecticut said: "The fundamental law which God and nature has given to the people cannot be infringed. . . . The right of property is such a fundamental

the preservation of these inviolate, may justly be said to include the preservation of our civil communities in their largest and most extensive sense ....

Life is the immediate gift of God, a right inherent by nature in every individual.

A man's limbs . . . are also the gift of the wise Creator . . To these therefore he has a natural inherent right.

The security of his reputation or good name from the arts of detraction and slander, are rights to which every man is entitled by reason and natural justice.

The third absolute right, inherent in every Englishman, is that of property. The origin of private property is probably founded in nature." Comm. I, pp. I29-I38.

$=$ Sir Frederick Pollock maintains that Blackstone used the natural law doctrine merely to ornament the introductory chapters of his Commentaries, cf. "History of the Law of Nature," I Columbia Law Review, 3I.

${ }^{3}$ Jefferson's (Va.) Reports, p. II4 (I772).

"2 8 Co. Ir8a.

${ }^{25} 7$ Co. I4a. 
right." ${ }^{26}$ The case along with the precedents cited gives evidence that the common law was regarded by the colonists as expressive of the law of nature and the law of God. ${ }^{27}$ In fact the judges in the colonies were impressed with the overruling authority of the laws of God and natural laws which were regarded as the true law, and temporal legislation was considered to be binding only in so far as it was an expression of this law. "With such a view of the nature of legal obligations," says Professor Reinsch, "it does not seem strange that magistrates should look for the true law in their own sense of right and justice, or, in the Puritan colonies, in the word of God."28

It is a matter of common knowledge that natural law and natural rights were among the dominant ideas of the leaders of the American Revolution as well as the framers of our first constitutions. James Otis, ${ }^{29}$ Samuel Adams, John Adams, ${ }^{30}$ Thomas Paine, Patrick Henry and Thomas Jefferson, with a host of others, combined to render the natural rights notion popular. According to the Declaration of Independence men are "endowed with certain inalienable rights, among these are life, liberty, and the pursuit of happiness." Many of the revolutionary patriots believed with Dickinson that liberties do not result from charters; charters rather are in the nature of declarations of pre-existing rights. They are founded, according to John Adams, "in the frame of human nature, rooted in the constitution of the intellectual and moral world." Most significant of all is the fact that constitutions, federal and state, were framed when the natural rights philosophy was particularly prevalent. In bills of rights, in occasional phrases in the body of constitutions and in the general opinion regarding the nature of constitutions are to be found evidences of natural rights, such, for example, as are expressed in the New Hampshire constitution that, "all men have certain natural, essential, and inherent rights; among which are-the

${ }^{20}$ Giddings v. Brown ; Reinsch, "Colonial Common Law," Select Essays in Anglo-American Legal History, Vol. I, p. 376; see also reference by Patrick Henry to the law of nature as superior to ordinary law, Elliott's Debates, Vol. 3, pp. I39-I40.

${ }^{27}$ Ibid., p. 377.

${ }^{28}$ Select Essays in Anglo-American Legal History, Vol. I, p. 413; The American Doctrine of Judicial Supremacy, pp. 20, ff.

${ }^{20}$ See Quincy's Reports (Mass.) 474, where /an act against natural equity is declared to be void.

${ }^{30}$ Quincy's Reports, 200 . 
enjoying and defending of life and liberty-acquiring, possessing and protecting property - and in a word, of seeking and obtaining happiness." 31 It was pretty generally thought that governments were instituted primarily to render more secure these pre-existing rights. $^{32}$

Although the prevalence of natural rights, based upon a fundamental and immutable natural law, in the colonial and revolutionary periods is usually conceded, it is customary to assert that the doctrine of natural rights and natural law has had little acceptance as a basis for judicial decisions in the public law of the United States.

It is the practice to insist that while references to these phrases are somewhat frequent the utterances are almost invariably in the form of dicta, the decision resting on other grounds, and involving specific provisions of the written constitution. Some writers, evidently misled by the differences in terminology in AngloAmerican and continental European countries and unaware of the significance of judicial decisions along this line, have even asserted that there is no such thing as law of nature or law of reason in American law except in some obiter opinions. While there is some merit in this contention and while the courts have seldom openly and avowedly used natural law notions or the doctrine of general principles of justice as the sole basis of a decision to invalidate legislation, it can be readily shown that the popular theory as to the lack of the influence and importance of natural law in the constitutional law of the United States does not give due consideration to the prevalence of this idea in judicial decisions. By a citation of cases, federal and state, attention will be called to the tendency to use natural law principles as a direct basis to invalidate legislation and also as an implied ground to broaden and render more effective the specific language of written constitutions in the development of judicial review of legislation.

Natural Law as a Basis for Extra-Constitutional Limitations upon the Power of Legislation. Whether there are limitations on legislation other than those definitely and expressly outlined in constitutions is one of the moot questions of American constitutional law. According to one view there are no such limitations, the courts have no authority whatever to interpose additional restrictions to those defined in the constitution and the opinions

${ }^{31}$ Bill of Rights, Sec. II ( $\left.I 784\right)$.

${ }^{20}$ Cf. Merriam, American Political Theories, pp. 48, 49. 
favoring such a procedure are held to be in the nature of dicta and in no sense the basis for judicial judgments. From another viewpoint the very nature of free government requires such additional limitations, the general principles of justice demand them and governments were constituted in the United States with these fundamental limitations clearly understood and appreciated. Courts in applying these general principles of justice and liberty, it is contended, are performing the most sacred function allotted to them under free governments as conceived and developed on this continent. Each of these rather divergent views has earnest and able advocates. Each has received judicial sanction in numerous cases. In an effort to deal with the advocacy of extraconstitutional limitations there is no disposition to underestimate the significance or to ignore the potency of the opposite doctrine.

A court cannot declare a statute unconstitutional and void, says Judge Cooley, "solely on the ground of unjust and oppressive provisions, or because it is supposed to violate the natural, social or political rights of the citizen unless it can be shown that such injustice is prohibited or such rights guaranteed or protected by the constitution." ${ }^{33} \mathrm{He}$ admits that there are cases in which judges have intimated a different doctrine but rather by way of argument, he maintains, than with the object of setting limits to the extent of legislative power not imposed by the constitution. After the examination of some of the supposed extra-judicial opinions the conclusion is reached that "the rule of law upon this subject appears to be, that except where the constitution has imposed limits upon the legislative power, it must be considered as practically absolute, whether it operate according to natural justice or not in any particular case."34 A long list of citations is given in support of the contention that courts will not interpose objections to legislation because it is unwise or oppressive, that they will not interfere with the lawmaking power in the determination of matters of right, reason and expediency. ${ }^{35}$ Similarly, it is denied that courts may declare statutes void because they are thought to violate fundamental principles of republican government, or are opposed to the spirit supposed to pervade the constitution. ${ }^{36}$ Citations supporting this position can be extended

\footnotetext{
${ }^{33}$ Constitutional Limitations, p. I97.

ss Ibid., pp. 200, 201.

$\approx$ See p. 201, for citations to substantiate this conclusion.

${ }^{85}$ Cooley, pp. 202-204, for discussion and citations. See also I Kent Comm. (12 ed.), p. 447; "if there be no constitutional objection to a
} 
indefinitely. ${ }^{3 \pi}$. To quote the language of the Supreme Court in a recent decision, "under the guise of interpreting the constitution we must take care that we do not import into the discussion our own personal views of what would be wise, just and fitting rules ' of government to be adopted by a free people and confound them with constitutional limitations." 38

The doctrine that there are extra-constitutional limitations and that the courts apply principles of reason, justice or fundamental principles of free government cannot be disposed of by simply characterizing the opinions thereupon as dicta. A notion of fundamental and inalienable rights which antedate government and condition its very existence is one of the pervasive ideas of American constitutional law. References to inherent limitations upon every form of law making and to restrictions upon legislatures along the line of fundamental rights are made frequently by justices under circumstances and conditions which render it impossible to dispose of their opinions as obiter or to rule them out entirely as not one of the controlling grounds for the decisions.

Even Judge Cooley, who states so positively the theory of legislative supremacy within the limits defined by the constitution, qualifies this theory in a marked degree by admitting the principle of extra-constitutional limitations. "It does not follow, however," he remarks, "that in every case the courts, before they can set aside a law as invalid, must be able to find in the constitu-

statute, it is with us as absolute and uncontrollable as laws flowing from the sovereign power under any other form of government." I Comm. I4I. Cf. also, Thayer, Legal Essays, for the opinion-"It may be remarked here that the doctrine of declaring legislative acts void as being contrary to the constitution, was probably helped into existence by a theory which found some favor among our ancestors at the time of the revolution, that courts might disregard such acts if they were contrary to the fundamental maxims of morality, or, as it was phrased, to the law of nature. Such a doctrine was thought to have been asserted by English writers, and even by judges at times, but was never acted on. It has been repeated here, as a matter of speculation, by our earlier judges, and occasionally by later ones; but in no case within my knowledge has it ever been enforced where it was the single and necessary ground of the decision, nor can it be, unless as a revolutionary measure," pp. $6,7$.

${ }^{37}$ For a list of Supreme Court cases and other citations, cf., R. P. Reeder, Constitutional and Extra-Constitutional Restraints, $6 \mathrm{I}$ University of Pennsylvania Law Review, 446 .

${ }^{3}$ Twining v. New Jersey, 21 I U. S. 78, 106, 107 (I908). 
tion some specific inhibitions on legislative power." He cites as illustrations of such limitations:-(I) a legislature can only exercise legislative power; (2) taxation cannot be arbitrary nor for any but a public purpose; (3) the right of self government, an inseparable incident to republican government, cannot be taken away; (4) passing one man's property over to another would of course be void. The maxims of Magna Charta and the common law are held to be interpreters of constitutional grants of power, and such acts as are forbidden by these maxims are not to be regarded as within the grant to the various departments of government. ${ }^{3 \theta}$

The extent to which the theory of extra-constitutional limitations inheres as a determining factor in the development of constitutional law in the United States and the various ways by which the theory exerts an influence in particular judicial opinions and in the development of entire branches of constitutional law can best be shown in a survey of decisions. Some general statements of the natural law doctrine will first be presented and then attention will be directed to the application of the doctrine as one of the concrete rules in determining cases.

Opinions Favoring the Doctrine of Natural Law as a Basis for Extra-Constitutional Limitations. Some of the earliest and most notable opinions are known to have been in the nature of dicta. A few at least of these opinions are worthy of citation since the dicta were later accepted as the statement of a fundamental constitutional tenet. Only a few instances can be referred to here; other illustrations will be noted under the special limitations imposed as an outgrowth of natural law notions. As far as possible those cases which are regarded as representative precedents have been selected among the numerous opinions referring to natural law.

Justice Chase believed that there are principles in our free republican governments which will determine and overrule an apparent and flagrant abuse of positive law. An act of the legislature contrary to the first principles of the social compact cannot, he thinks, be considered a rightful exercise of legislative authority. ${ }^{40}$ A law that punishes a citizen for an innocent action and

\footnotetext{
${ }^{39}$ Constitutional Limitations, pp. 206-8; like Blackstone and some of his successors Cooley appears to be on both sides of the natural law controversy.

${ }^{40}$ Calder v. Bull, 3 Dallas, 388 (I798); Justice Iredell regards the reference to general principles as unnecessary and gives his opinion as
} 
one that makes a man judge in his own cause were cited as examples of legislative acts prohibited by the genius, the nature, and the spirit of our state governments and by the general principles of law and reason. ${ }^{41}$ Chief Justice Marshall in the famous case of Fletcher v. Peck, involving an interference by a state legislative act with vested property rights, said:

"It may well be doubted whether the nature of society and of government does not prescribe some limits to the legislative power; and if any be prescribed, where are they to be found, if the property of an individual, fairly and honestly acquired, may be seized without compensation?" 42

The general principle that rights vested under a contract are beyond legislative attack is strongly affirmed but the decision is placed directly upon the provision of the constitution denying to the states the right to impair the obligation of contracts.

As an advocate of extra-constitutional restraints Chancellor Kent maintained that such rules of construction must be followed as are agreeable to those settled rules which the wisdom of the common law has established for the interpretation of statutes, and are not inconvenient, nor against reason, and injure no person. A statute is never to be construed against the plain and obvious dictates of reason. The common law, says Lord Coke, adjudgeth a statute so far void; and upon this principle the Supreme Court of South Carolina proceeded; when it held that the courts were bound to give such a construction to a statute as was consistent with justice, though contrary to the letter of it. . . . It is not intended that we have any express constitutional provision on the subject; nor have we any for numerous other rights dear alike to freedom and to justice. A law impairing previously acquired rights was cited as equally to be condemned as those expressly prohibited. ${ }^{43}$ The authority of common sense and reason of

favorable to legislative omnipotence except so far as specific restrictions are defined in the constitution, pp. 398 , ff.

"Ibid., 388.

-Fletcher v. Peck, 6 Cranch 87, I35 (I8ro). See also, Terrett v. Taylor, 9 Cranch 43, 50 (I8I5), for reference by Justice Story to the sacredness of vested rights of property as a principle "consonant with the common sense of mankind and the maxims of eternal justice" and the opposite doctrine as "utterly inconsistent with a great and fundamental principle of republican government."

${ }^{3}$ Dash v. Van Kleeck, 7 Johns. 477, 502, 505 (I8II). 
civilized states was in his opinion regarded as sufficient to cause "not only the judicial, but even the legislative authority to bow with reverence to such a sanction." 44 In a subsequent case, ${ }^{45}$ Kent decided that as a principle of natural equity compensation was due the owner of property taken by the state even in the absence of any constitutional provision to that effect and that the power of eminent domain could be exercised for public purposes only. According to his view the police power was surrounded by the same limitations. ${ }^{46}$

In Wilkinson v. Leland, Webster and Story strongly supported the notion of extra-constitutional protection to vested rights. "If at this period," said Webster, "there is not a general restraint on legislatures, in favor of private rights, there is an end to private property. Though there may be no prohibition in the constitution, the legislature is restrained from committing flagrant acts, from acts subverting the great principles of republican liberty, and of the social compact," $4 \pi$ and Justice Story, agreeing with Webster, in the course of his opinion observed:

"The fundamental maxims of a free government seem to require, that the rights of personal liberty and private property should be held sacred. At least no court of justice in this country would be warranted in assuming, that the power to violate and disregard them-a power so repugnant to the common principles of justice and civil liberty,-lurked under any general grant of legislative authority or ought to be implied from any general expressions of the will of the people." 48

Not a few of the justices of the state supreme courts assert similar views. The Court of South Carolina thinks it is clear, "that statutes passed against the plain and obvious principles of common right and common reason are absolutely null and void." We are bound to give such a construction to the act "as will be consistent with justice and the dictates of natural reason, though contrary to the strict letter of the law."49 In Virginia, where the natural rights philosophy was prevalent, Justice Wythe main-

"Ibid., p. 508.

${ }^{45}$ Gardner v. Newburgh, 2 Johns. I62 (1816).

${ }^{43} 2$ Comm., pp. 328-330; Corwin, Due Process of Law before the Civil War, 24 Harvard Law Review, 375 .

${ }^{17} 2$ Peters, 627, 646 (I829).

${ }^{4}$ Ibid., 657.

'Ham v. McClaws, I Bay 93, 98 (I789). 
tained that the authority of the legislature could not prevail against the law of nature and of nations. ${ }^{50}$ Justice Ormond of Alabama held that any act of the legislature which violates the great principles of civil liberty or inherent rights of man is void. No power is delegated to invade these great natural rights. ${ }^{51}$

That statutes contrary to the principles of natural justice are void whether prohibited by the constitution or not is not infrequently declared by the courts both state and federal. "There are," says the Supreme Court of Tennessee in affirming this doctrine, "eternal principles of justice which no government has a right to disregard. It does not follow, therefore, because there may be no restriction in the constitution prohibiting a particular act of the legislature, that such act is therefore constitutional. Some acts, although not expressly forbidden, may be against the plain and obvious dictates of reason. The common law, says Lord Coke (8 Co. II8 a.), adjudgeth a statute so far void."52

While the theory of extra-constitutional limitations was developed in the first quarter of the nineteenth century, it was after

"Page v. Pendleton, Wythe, Ref. (Va.) 2II, 215 (I793).

${ }^{51}$ Ex parte Dorsey, 7 Porter 293, 377, ff. (I838); Justice Ormond thought the act in question came within the section of the bill of rights reserving to the people all powers not specifically granted to the government; consequently he did not rest his opinion on the doctrine of natural justice although his approval of the doctrine is evident. The natural rights ground for the decision was condemned by Chief Justice Collier who denied to the judiciary the right to declare an act of the legislature void unless it be "violative of the constitution or of some one of its provisions."

"Bank of State v. Cooper, 2 Yerg. 599, 603 ( 1831 ). The decision is based on the ground of the denial of equal operation of the laws and as being contrary to the law of land provision of the constitution. Hosmer, C. J., in Goshen v. Stonington, says, "with those judges who assert the omnipotence of the legislature in all cases where the constitution has not interposed an explicit restraint, I cannot agree." An infraction of vested rights would be a violation of the social compact and within the control of the judiciary. 4 Conn. 209, 225 (I822).

"The legislative power of this state extends to every proper object of legislation, and is limited only by our constitutions and by the fundamental principles of all government and the inalienable rights of mankind." Richardson, C. J., in Dartmouth College v. Woodward, I N. H. III, II4 (I8I7). See also, Benson v. Mayor, ro Barb. 223, 244 (I850), wherein the court, in defense of vested rights, says: "Their rights, in this respect, rest not merely upon the constitution but upon the great principles of eternal justice which lie at the foundation of all free government." 
the Civil War that there was something in the nature of a revival of the earlier natural rights theory, particularly in the interpretation of some of the general phrases relative to individual rights in federal and state constitutions. A great defender of the theory was Justice Field. He referred frequently to the natural and inalienable rights which belong to all citizens and declared that the Fourteenth Amendment was intended "to give practical effect to the declaration of 1776 of inalienable rights, rights which are the gift of the Creator, which the law does not confer but only recognizes." The classic presentation of the theory of implied limitations is that of Justice Field in Butchers' Union Co. v. Crescent City Co., where he amplified his notions. Certain inherent rights he claimed lie at the foundation of all action and by a recognition of these alone can free institutions be maintained. Among these rights are declared to be the pursuit of a lawful avocation and the enjoyment of property. He continued:

"I cannot believe that what is termed in the Declaration of Independence a God-given and an inalienable right can be thus ruthlessly taken from the citizen, or that there can be any abridgment of the right except by regulations alike affecting all persons of the same age, sex, and condition. . . The right to follow any of the common occupations of life is an inalienable right; it was formulated as such under the phrase 'pursuit of happiness' in the Declaration of Independence. This right is a large ingredient in the civil liberty of the citizen. To deny it to all but a few famed individuals, by investing the latter with a monopoly, is to invade one of the fundamental privileges of the citizen, contrary not only to common right, but, as I think, to express words of the constitution.""se

- In support of this contention of Justice Field, Justice Brewer claimed that the first ten amendments to the Federal Constitution were enacted to protect those rights of person and property which

See especially the dissenting opinion in the Slaughter House Cases, 16 Wall. 36, Io5 (1872); also, Cummings v. Missouri, 4 Wall. 277, $32 \mathrm{I}$ (I866), "The theory upon which our political institutions rests is, that all men have certain inalienable rights-that among these are life, liberty, and the pursuit of happiness; and that in the pursuit of happiness all avocations, all honors, all positions, are alike open to every one, and that in the protection of these rights all are equal before the law."

III U. S. 746,756 , ff. (I883). For the influence of this case in the development of the constitutional concept of liberty of contract, cf. Pound, Liberty of Contract, I8 Yale Law Journal, 454. 
by the Declaration of Independence were affirmed to be inalienable rights. ${ }^{55}$

The well known opinion of Justice Miller puts in even more positive form the position of Justices Field and Brewer. "It must be conceded that there are rights in every free government beyond the control of the state. A government which recognized no such rights, but held the lives, the liberty, and the property of its citizens subject at all times to the absolute disposition and unlimited control of even the most democratic depository of power is, after all, but a despotism of the many-of the majority, but none the less a despotism. . . . The theory of our governments, state and national, is opposed to the deposit of unlimited power anywhere."5s Such general statements were soon more definitely formulated under the designation, fundamental rights, a term which has an interesting development under the aegis of the Fourteenth Amendment. ${ }^{57}$ "There are," said Justice Matthews of the Supreme Court, quoting with approval from the Supreme Court of Mississippi, 50 Miss. 468, "Certain fundamental rights, which that system of jurisprudence, of which ours is a derivative, has always recognized."'ss The powers of legislatures are held to be limited by "those fundamental principles of liberty and justice which lie at the base of all our civil and political institutions." "Ts The court later approved full control over the procedure "subject only to the qualifications that such

${ }^{*}$ Monongahela Navigation Co. v. U. S., I48 U. S. 3I2, 325 (I892); Justice Brewer quoted approvingly the doctrine of extra-constitutional limitations but found it unnecessary to base his opinion on natural equity or the affirmations of the Declaration of Independence.

${ }^{-}$Loan Association v. Topeka, 20 Wall. 655, 662 (1874).

"57 "It may be admitted that the words due process of law as used in the Fourteenth Amendment protect fundamental rights." Howard $v$. Kentucky, 200 U. S. 164, 173 (1906); also, Twining v. N. J., 2II U. S. 78, 102 (1908). In defining due process the court says: "It is sufficient to say that there are certain immutable principles of justice which inhere in the very idea of free government which no member of the Union may disregard." Holden v. Hardy, 169 U. S. 366,389 (I897).

${ }^{88}$ Hurtado v. California, I10 U. S. 516, 536 (1883).

${ }^{\omega}$ In re Kemmler, I36 U. S. 436; 448 (I889). See also, Hagar Reclamation Dist. No. 108, III U. S. 70I, 709 (I885), for reference to "Those general principles established in our system of jurisprudence for the security of private rights." West $v$. Louisiana, r94 U. S. 258, 263 (1903). The proceedings of state courts "must not work a denial of fundamental rights or conflict with specific and applicable provisions of the Federal Constitution." 
procedure must not work a denial of fundamental rights or conflict with specific and applicable provisions of the Federal Constitution." 60 That it is the business of the federal courts to protect fundamental rights has been declared in numerous decisions. ${ }^{61}$

This series of opinions on extra-constitutional limitations may well be concluded with a few recent pronouncements of state courts. The Supreme Court of Kentucky through Chief Justice Hines maintained that:

"An act of the legislature may be unconstitutional because impliedly forbidden by the constitution, or because expressly thereby forbidden. An act is, by implication, unconstitutional when not legislative in nature; such as an act taking the property of one citizen and giving it to another, or an act making one judge in his own case. Such attempted legislation is arbitrary and despotic, not in its nature legislative, the legislative department of the government being limited by its nature as the executive and judicial, their respective powers being circumscribed by the rules of Magna Charta and of the common law, constitutions not generally undertaking to define the duties and power of either of these branches of the government. When the legislation is in terms forbidden, we need look no further in order to declare it unconstitutional, but when it is not so denounced, we have the more delicate task of inquiring as to the nature and limit of legislative power." ${ }^{\prime 2}$

A similar conclusion was reached in Commonwealth v. Perry, when the Supreme Court of Massachusetts held a statute which violated fundamental rights as unconstitutional and void even though the enactment of it was not expressly forbidden. ${ }^{63}$ That the state has no right to invade the domain of private rights reserved by the citizen in the formation of government is the claim of the Supreme Court of Georgia. Among the rights

${ }^{\circ}$ Brown v. N. J., I75 U. S. I72, I75 (1899); Cf. West v. Lotisiana, 194 U. S. 258, 263 (1903) ; Waters-Pierce Oil Co. v. Texas, 2I2 U. S. 86, Io7 (I909); see also dissent of Justice Harlan, Pollock v. Farmers Loan and Trust Co., I58 U. S. 6or, 674-5 (I894).

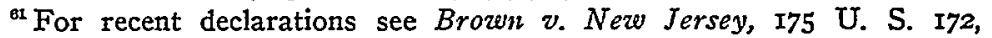
I75 (I899); Rogers v. Peck, I99 U. S. 425, 434 (I905); Ballard v. Hunter, 204 U. S. 24I, 262 (I907) and Watson v. Maryland, 218 U. S. I73, I77 (1909).

${ }^{2}$ Barbour v. Louisville Board of Trade, $82 \mathrm{Ky} .645,648$ (I884).

${ }^{\text {es }}$ I55 Mass. Ir7 (I87I). 
reserved, in the opinion of the court, are the great natural rights of the individual:-

"A right of privacy in matters purely private is therefore derived from natural law. This idea is embraced in the Roman's conception of justice, which 'was not simply the external legality of acts, but the accord of external acts with the precepts of the law prompted by internal impulse and free volition.' It may be said to arise out of those laws sometimes characterized as immutable, "because they are natural, and so just at all times, and in all places, that no authority can either change or abolish them."

The liberty which the individual derives from natural law, and which is recognized by municipal law, embraces far more, says the court, than freedom from physical restraint. The term liberty is deemed to embrace the right of a man to be free in the enjoyment of the faculties with which he has been endowed by his creator, subject only to such restraints as are necessary for the common welfare. . . The right of one to use his faculties in all lawful ways, to live and work where he will, to earn his livelihood in any lawful calling, and to pursue any lawful trade or avocation. ${ }^{64}$

A few citations, some of which are in the nature of dicta, from among thousands of court decisions would tend to give the impression that natural law has a very slight influence on the constitutional jurisprudence of the United States. Although the courts, especially in the opinions of certain justices, are disposed to invalidate statutes on the ground of natural justice, inalienable right and reason, whether expressly prohibited by constitutions or not, it is customary to claim that the statutes involved are contrary both to natural law and to the constitution. Judging from the language used there is good reason to conclude that in

\footnotetext{
"Pavesich v. New England Life Insurance Co., I22 Ga. I90, I94-7 (I904); in addition to a violation of natural law the statute was also held contrary to the provision of the state constitution requiring due process of law. "The habit," says Justice Brewer, "of regarding the legislature as inherently omnipotent and looking to see what express restrictions the constitution has placed upon its action is dangerous, and tends to error. Rather regarding first those essential truths, those axioms of civil and political liberty upon which all free governments are founded, and secondly those statements of principles in the Bills of Rights upon which this governmental structure is reared, we may properly then inquire what powers the words of the constitution, the terms of the grant, convey." State v. Nemeha County, 7 Kan. 549, 555 (I87I).
} 
not a few cases natural law is given first weight in the decision and that the act is held void primarily as contrary to natural justice and secondarily because contrary to some general provision of the constitution.

The opponents of natural law, however, give extraordinary emphasis to the references to the constitution. They maintain that there are few, if any, cases in which natural law is the sole ground of the decision and that consequently the notion may be discarded entirely from the realm of positive law. The answer to this conclusion is that natural law, natural justice and reason are seldom used as the sole basis for the decision chiefly because constitutional sanction, always very desirable, if not absolutely necessary, has been found in a broad interpretation of the phrases, law of the land or due process, so as to inhibit acts regarded as arbitrary and undesirable, ${ }^{85}$ or in the general reservation favorable to individual liberty in the bill of rights, ${ }^{66}$ or in the requirement that laws be reasonable or wholesome and not unjust, oppressive and inconsistent with the fundamental principles of free government, ${ }^{67}$ or in a version of the theory of separation of powers, declared to be a part of the constitution, by which statutes considered unjust or unreasonable are held to be not legislative in nature. ${ }^{68}$ It is rather that natural law notions have been brought under the specific language of the constitution by judicial interpretation or by the expansion of certain phrases of the written instrument than that the idea has been either ignored or discarded. The process by which certain ideas involved in the law of nature were judicially declared within the language of the fundamental law constitutes an important step in the evolution of the legal concept in the United States. It is this process which renders natural law such an important principle in modern constitutional law.

\footnotetext{
${ }^{65}$ See cases, pp.

${ }^{\circ}$ Cf. Ex parte Dorsey, 7 Porter, 293.

"Massachusetts Constitution, I780; New Hampshire, I784; Maine, 1819; see also provisions in constitutions of Kentucky and Wyoming to the effect "absolute and arbitrary power over the lives, liberty and property of freemen exists nowhere in a republic, not even in the largest majority."

${ }^{\infty}$ Cf. Barbour v. Louisville Board of Trade, $82 \mathrm{Ky} .645$.
} 


\section{III}

What, then, are the fundamental and inalienable rights for the preservation of which governments are declared to be instituted among men? If these fundamental rights are no other than the eighteenth century inalienable rights of Blackstone and the Declaration a fairly good case is made for the recurrence of natural law in recent judicial decisions.

According to Blackstone the absolute rights of individuals are: (I) the right of personal security; (2) the right of personal liberty; (3) the absolute right of property. ${ }^{69}$ Practically all of the so-called fundamental rights are to be found under one of these general classes but only certain specific applications of them have been held to come within the implied inhibitions on legislative power. The majority of precedents involving the doctrine of fundamental and inalienable rights are comprehended under: (I) interference with property rights such as the taking of property from one individual and giving it to another, or the taking of property without just compensation; (2) interference with the personal liberty, right of contract and pursuit of one's calling so as to deny equal and impartial application of the law; (3) unfairness or injustice in trial or court procedure, such as the rendering of judgments without personal service. ${ }^{70}$

In the early years of judicial review of legislation it was not unusual to refer to the fundamental rights as being protected by the law of nature, natural justice, the social compact or the natural incidents of a free, republican government. In a few instances the law of the land clause, which was considered as applying primarily to judicial procedure and methods of trial ${ }^{71}$ and consequently was given a rather narrow application, was used as a basis to protect personal rights. ${ }^{72}$ Gradually as occasions for

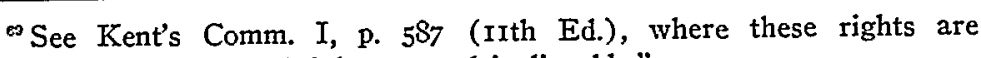
declared to be "natural, inherent and inalienable."

${ }^{70}$ Cf. More v. State, 43 N. J. L. 203, 243, 244 (I88I), wherein Justice Van Syckel dissenting, claims that the rights for which immunity against encroachments of the lawmaker outside of the express provisions of the constitution can be claimed are confined to three instances, viz., the right to private property, to notice and a hearing before judgment, and the principle that a judge shall not be made a judge in his own case.

${ }^{7}$ McKechnie, Magna Carta, p. 44I ; Pike, Constitutional History of the House of Lords, p. I69.

72 That the law of land in Magna Carta was understood as a rather broad guarantee against arbitrary power is the conclusion of McIlwaine, 
the exercise of judicial review increased and courts were disposed to set more specific limits to legislative power the doctrine of fundamental and inalienable rights was combined with the due process clause. The combination was accomplished by defining due process as an inhibition against laws either arbitrary or partial in their operation and thus the rule of reason was given constitutional sanction. By the addition of the phrase, equal protection, in the Fourteenth Amendment the rule of reason acquired additional force. As time went on due process and equal protection were ordinarily referred to as the specific ground for the protection of fundamental rights. ${ }^{73} \mathrm{~A}$ basis for their application having been gradually discovered in constitutions by broadening the scope of due process, it became unpopular with lawyers and judges to refer to fundamental rights, natural law and justice or to the general principles of republican government. But fundamental rights remain about the same, whether used as

Due process of Law in Magna Carta, I4 Columbian Law Review, 28. The interpretation of the provision by Coke was accepted and followed in America. See 2 Haywood (N. C.) 29, 38, wherein Attorney-General Haywood contended that the law of the land provision of the state constitution was a declaration "not against a power they supposed their own representatives might usurp but against oppression and usurpation in general." Cf. also Mayo v. Wilson, I N. H. 58; Zylstra v. Corporation of Charleston, x Bay (S. C.) 384 (I794) and especially North Carolina $v$. Foy, 2 Haywood 3ro (I804). These and other early precedents are discussed in Corwin's The Doctrine of Due Process of Law before the Civil War, 24 Harvard Law Review, 366, 460.

${ }^{73} \mathrm{On}$ the development of due process and the absorption of natural law and natural rights under this term and the doctrine of separation of powers, see Corwin, The Doctrine of Due Process of Law before the Civil War and The Basic Doctrine of American Constitutional Law, I2 Michigan Law Review, 247. "It is no longer good form, because it is no longer necessary, for a court to invoke natural rights and the social compact in a constitutional decision. But the same result is achieved by construing the very term by which legislative power is conferred upon the legislature. Natural rights expelled from the front door of the constitution are readmitted through the doctrine of the separation of powers," p. 252. See also, The Evolution of Due Process of Law in Decisions of the United States Supreme Court, by F. W. Bird, I3 Columbian Law Review, 37-50, for a discussion of the expansion of due process to include the former idea of fundamental rights; also Hand, Due Process of Law and the Eight Hour Day, 2I Harvard Law Review, 495; the Fourteenth Amendment, says Justice Waite of the Supreme Court, "simply furnishes an additional guarantee against any encroachment by the states upon the fundamental rights which belong to every citizen as a member of society." U. S. v. Cruikshank, 92 U. S. 542, 554 (1875). 
an extra-constitutional doctrine to invalidate acts or whether read into due process in order to give the decision a cloak of constitutional sanction. It is noteworthy that courts continue to refer to the doctrine of natural and inalienable rights long after due process has been extended to cover all possible cases of legislative power which might be considered by judges as arbitrary or oppressive.

An accurate valuation of natural law in the judicial decisions of the United States would involve an exhaustive treatment of certain phases of vested rights, of due process and equal protection of the laws, of standards of reasonableness, of justice and public purpose as well as of other implied limitations on legislative power. Some representative citations merely can be given here to show the development and continuance of natural law ideas as a controlling or supplementary ground in the consideration of the validity of legislative acts. Natural law will be briefly considered both in connection with specific phrases of written constitutions and as an independent basis for judicial review with respect to: (I) protection to property and contract-vested rights; (2) an inhibition against arbitrary power in government; (3) protection against arbitrary acts affecting individual liberty, freedom of contract; (4) the application of the test of reasonableness to the police power, to rate regulation, and to social and industrial legislation in general.

I. Protection to Property and Contract-Vested Rights. Soon after the federal government was established in the United States Justice Patterson, starting a long line of opinions denying to the legislature the right to interfere with vested property rights, said: "It is inconsistent with the principles of reason, justice, and moral rectitude; it is incompatible with the comfort, peace and happiness of mankind; it is contrary to the principles of social alliance, in every free government; and lastly, it is contrary to both the letter and spirit of the constitution."74 Soon thereafter came the important judgment of the Supreme Court of North Carolina that a contract cannot be dissolved even by a legislative act because of a principle "incorporated into the inevitable law of natural justice" which no power on earth can overturn. The law of land provision of the constitution was held to be a very definite restriction on the power of the legis-

"Vanhornes Lessee v. Dorrance, 2 Dallas, 304, 310 (1795). 
lature with respect to vested rights. "When a law is in its. nature a contract," said Marshall, "when absolute rights have vested under that contract, a repeal of the law cannot divest those rights."76 A legislative act which attempted to interfere with the property rights of a corporation acquired under previous laws is invalid, said the Federal Supreme Court, the decision, according to Justice Story, "standing upon the principles of natural justice, upon the fundamental laws of every free government, upon the spirit and letter of the Constitution of the United States." 77 A similar effort to interfere with the obligation of contract in the state of Maryland was declared void with the observation that independent of any express restriction in the constitutions of the United States and of that ștate "there is a fundamental principle of right and justice, inherent in the nature and spirit of the social compact, (in this country at least) . . . that rises above and restrains and sets bounds to the power of legislation." 78

In declaring void a statute authorizing a private road to be laid out over the lands of a person without his consent, Justice Bronson held, "the security of life, liberty and property, lies at the foundation of the social compact; and to say that this grant of legislative power includes the right to attack private property, is equivalent to saying that the people have delegated to their servants the power of defeating one of the great ends for which the government was established."'79 According to another court, no one can be deprived of a part or a whole of his property unless the public good requires it. ${ }^{80}$ In determining whether a police regulation for the preservation of health serves the public good, the court was obliged to fall back on the doctrine of reasonableness. When the question was asked what section of the constitution had been violated by the act in question, "It is answer enough to say," Justice Peck replied, "that the act takes away from some

${ }^{75}$ Trustees of the University of North Carolina v. Foy, 2 Hay. 3Io (1804).

${ }^{76}$ Fletcher v. Peck, 6 Cranch, 87, I35 (I8ro).

"Terrett v. Taylor, 9 Cranch, 43, 5I (I8I5).

${ }^{78} \mathrm{Md}$. Regents v. Williams, $9 \mathrm{G}$. \& J. 365, 408 (1838).

${ }_{4} 4$ Hill, I40, I45 (I843). See Sinyvesant v. The Mayor, wherein the court refers to "a fundamental principle of civilized society, that private property shall not be taken even for public use without just compensation," 7 Cow. 585, 606 (1827).

${ }^{\text {so }}$ Austin v. Murray, I6 Pick. I2r, 126 (1834-5). 
their vested rights and gives them to others; changes the nature of obligations, and dispenses with the liabilities which all others in similar situations would lie under."

The Supreme Court of New York denied to the legislature the authority to affect certain rights "because it is beyond the scope of legislative authority to destroy vested rights of property," 82 and held invalid an act for the more effectual protection of the property of married women for the reason that the people have never delegated to the legislature the power to divest the vested rights of property legally acquired by any citizen of the state, and transfer them to another, against the will of the owner. Says Justice Mason,

"I maintain, therefore, that the security of the citizen against such arbitrary legislation rests upon the broader and more solid ground of natural rights and is not wholly dependent upon these negatives upon the legislative power contained in the constitution . . . the exercise of such a power is incompatible with the nature and object of all government, and is destructive of the great end and aim for which government is instituted, and is subversive of the fundamental principles upon which all free governments are organized.", ${ }^{83}$

The protection of property was early brought under the law of the land provision of the constitution ${ }^{84}$ and with the support of the doctrine of natural and inalienable rights, it was eventually formulated as a principle that "every individual has a right, under the constitution, to be protected in the enjoyment of his property, and no one can be wholly and entirely deprived of it by having it taken from him and transferred to another, without compensation or benefit in any way by a special act of legislation." vested rights of property are protected both on the theory of

s1 Officer v. Young, 5 Yerg. (Tenn.) 320, 322 (I833).

8 Holmes $v$. Holmes, 4 Barb. 295, 300 (1848). See the earlier case of Gardner $v$. Newburgh, in which it is claimed that in the absence of a constitutional provision compensation is due the owner of property taken by the state. 2 Johns. 162,165 (I8I6).

${ }^{53}$ White v. White, 5 Barb. 474 (1849).

"See Trustees of the University of North Carolina v. Foy, 2 Hay. 3Io (ISO4).

${ }^{80}$ Sohier v. The Massachusetts General Hospital, 3 Cush. 483, 493 (I849). 
inalienable rights and on the express provision of the constitution was held by the courts of New York ${ }^{88}$ and Massachusetts. ${ }^{87}$

Although vested rights after the adoption of the Fourteenth Amendment are considered as well within the protection of the - language of the due process provisions of federal and state constitutions and thus are construed as having constitutional protection it is not uncommon to find the continuance of references in judicial opinions to natural and fundamental rights as a basis for invalidating acts which interfere with vested rights. These references are to be found in both federal and state decisions.

A few recent opinions of state courts affirming the continuance of natural right as a basis for the protection of property illustrate this practice. The right to transmit property by descent or by will, says a Wisconsin court, is an inherent right protected by the constitution, and though subject to reasonable regulation, cannot be wholly taken away or substantially impaired by the legislature. Our theory is that the people, in full possession of inalienable rights, form the government to protect those rights.

"So clear does it seem to us from the historical point of view that the right to take property by inheritance or will has existed in some form among civilized nations from the time when the memory of man runneth not to the contrary, and so conclusive seems the argument that these rights are a part of the inherent rights which governments under our conception are established to conserve, that we feel entirely justified in rejecting the dictum so frequently asserted by such a vast array of courts that these rights are purely statutory and may be wholly taken away by the legislature." 88

"There are certain fundamental rights of every citizen," says the Massachusetts Supreme Court, "which are recognized in the organic law of all our free American states. A statute which violates any of these rights is unconstitutional and void, even though the enactment of it is not expressly forbidden. . . . The right to acquire, possess, and protect property includes the right

${ }^{86}$ Wynhamer $v$. State of N. Y., I3 N. Y. 378 (1856); Justice Hubbard dissented, asserting that he was "opposed to the judiciary attempting to set bounds to legislative authority, or declaring a statute invalid upon any fanciful theory of higher law or first principles of natural right outside of the constitution," p. 453.

${ }^{5}$ Denny v. Matton, 84 Mass. 36I (I86x).

${ }^{2}$ Numemacher, Trustee v. The State, I29 Wis. I90, 197-202. 
to make reasonable contracts, which shall be under the protection of the law." Both by the doctrine of inalienable rights and by the constitution, vested rights of property and contract are thus declared to be beyond legislative attack.

2. The Inhibition Against Arbitrary Power in Government. The extension of due process so as to cover the former scope of natural law was accomplished in part by including under this phrase, among other things, an inhibition against laws of an arbitrary nature affecting either the individual rights of person or property. Justice Chase was one of the first judges to deny to the legislature the right to pass arbitrary laws "contrary to the first principles of the social compact." The somewhat extrajudicial opinion of Chase found worthy defenders in the state courts where it was held that the design of the government, particularly of the due process clause, was "to exclude arbitrary power from every branch of the government." That arbitrary statutes are not the law of the land was affirmed by Justice Johnson in the notable comment: "as to the words from Magna Charta, incorporated into the constitution of Maryland, after volumes spoken and written with a view to their exposition, the good sense of mankind has at length settled down to this: That they were intended to secure the individual from the arbitrary exercise of the powers of government, unrestrained by the established principles of private right and distributive justice."'01 It remained for Justice Field to put this principle in such a form that it could be brought directly under the Fourteenth Amendment and thereby rendered more effective as a legal check on legislative power. In Butchers' Union Co. v. Crescent City Co., he claims that police regulations may be upheld "when such

${ }^{\circ}$ Conmonwealth v. Perry, I55 Mass. II7, I25 (I891). See also, for reference to inalienable rights, State $v$. Lynch, I02 N. E. 67x. (J. Wanamaker dissents and criticises judge-made restrictions on legislation.)

${ }^{\infty}$ See C. J. Gibson in Norman v. Heisk, 5 Watts and Serg. I7I, I73 (1843); Officer v. Young, 5 Yerg. (Tenn.) 320 (I833); Westerfelt v. Gregg, I2 N. X. 202 (1854); Clark v. Mitchell, 64 Mo. 564 (1877); Atchison v. N. Ry. Co v. Baty, 6 Neb. 37 (I877). According to Justice Gantt, "This one great end of government is the protection of the absolute right of individuals-the life, liberty, and property of each citizen of the state." The statute in question is held to be "repugnant to the fundamental principles in respect to individual rights, the limitations and guarantees of the constitution and the maxims of the common law," pp. 44, 47.

'Bank of Colmmbia v. Okely, 4 Wheaton, 235, 244 (I8I9). 
regulations do not conflict with any constitutional inhibition or natural right" and defines the purpose of the Fourteenth Amendment as a series of prohibitions "to prevent arbitrary invasion by state authority of the rights of person and property, and to secure to everyone the right to pursue his happiness, unrestrained except by just, equal and impartial laws."92

The general adoption of an inhibition against legislation regarded by the courts as arbitrary is sanctioned more recently by the Federal Supreme Court, when it decided, relative to procedure in state courts, that due process is satisfied by "a trial in a court of justice according to the modes of proceeding applicable to such a case, secured by laws operating on all alike, and not subjecting the individual to the arbitrary exercise of the powers of government unrestrained by the established principles of private right and distributive justice," ${ }^{33}$ and that the Fourteenth Amendment "legitimately operates to extend to the citizens and residents of the states the same protection against arbitrary state legislation affecting life, liberty and property as is offered by the Fifth Amendment against similar legislation by Congress." "94

State regulations relative to the police power are held not to be subject to federal interference "unless they are so utterly unreasonable and extravagant in their nature and purpose that the property and personal rights of the citizen are unnecessarily and in a manner wholly arbitrary interfered with or destroyed

${ }^{22}$ III U. S. 746, 759 (I883). See also, Davidson v. New Orleans, 96 U. S. 97 (I877) and Monongahela $B$. Co. v. U. S., for a rather enlightening confession "that the courts have rarely, if ever, felt themselves so restrained by technical rules that they could not find some remedy, consistent with the law, for acts, whether done by government or by individual persons, that violated natural justice or were hostile to the fundamental principles devised for the protection of the essential rights of property." 216 U. S. 177, I95 (rgog).

${ }^{23}$ Justice Harlan in Chicago, Burlington \& $R y$. Co. v. Chicago, 166 U. S. 226, 234 ( 1896 ), approving a similar decision in U. S. v. Cruikshank, 92 U. S. 542-554.

* Justice Peckham in Hibben v. Smith, I9r U. S. 310, 325 (1903). Says the court in a more recent case: "Consistently with the requirements of due process no change in ancient procedure can be made which disregards those fundamental principles to be ascertained from time to time by judicial action which have relation to process of law and protect the citizen in his private right and guard him against the arbitrary action of government." Twining $v$. New Jersey, 21I U. S. 78, IOI (I908). 
without due process of law." While generally, says a New York court, it is for the legislature to determine what laws are required to protect and secure the public health, "under the mere guise of police regulations it may not arbitrarily infringe upon personal or property rights." ${ }_{96}$ The requirement of public purpose in taxation is also an effort to prevent arbitrary legislative action. ${ }^{97}$ Even broader ground as a basis for protection against arbitrary statutes is suggested in the contention of courts that only legislative power has been vested in the legislature and that acts not considered within the scope of the general grant of power are of necessity arbitrary and must be declared void. ${ }^{88}$

3. Protection against arbitrary acts affecting individual liberty and freedom of contract constitutes a further extension of the natural law concept. When in I886 a store order act of the state of Pennsylvania was held to be utterly unconstitutional as an arbitrary attempt to prevent persons from making their own contracts $^{\text {99 }}$ a fruitful field was discovered for further limitations on legislative power in accordance with the theory of inalienable rights. With Justice Field's opinion supporting freedom of contract and of calling ${ }^{100}$ and with a strong state precedent it was not long until state courts, jealous of the encroachments upon individual rights in the realm of social legislation, were led to defend liberty of contract as a natural and inalienable right. Says an Ohio court,

"Manifestly, of all the rights of persons, it is the most sacred and most essential to the happiness of all mankind. We do not believe that, in good conscience, the right to make any lawful contract can be limited or controlled by

\footnotetext{
${ }^{25}$ Justice Peckham in Gundling v. City of Chicago, I77 U. S. I83, I88, (1900). Acts are to be upheld, says Justice Harlan, "unless they are clearly inconsistent with some power granted to the general government, or with some right secured by that instrument or unless they are purely arbitrary in their nature." Chicago Rock Island \& Pac. Ry. Co. v. Arkansas, 219 U. S. 453, 465 (I9IO).

sin re Jacobs, $98 \mathrm{~N}$. Y. 98 , I Io (I885).

"Loan Association v. Topeka, 2o Wall, 655 and Cole v. La Grange.

${ }^{5}$ Wynhaner v. The People, I3 N. Y. 378, 385 (I856); State v. U. S. and Canada Express Co., 60 N. H. 219, 235 (I880); also dissenting opinion of Justice Ranney, Cass v. Dillon, 2 Ohio St. 607, 628 (I853) and Justice Connor in Daniels v. Homer, I39 N. C. 219, 237 (1905), and Justice Walker, State v. Lerris, I42 N. C. 626, 645 (I906).

"Godcharles $v$. Wigeman, Ir3 Pa. St. 43I (I886).

${ }^{10}$ Butcher's Union v. Crescent City Co., III U. S. 746.
} 
legislation determined by no rule or principle, that is purely arbitrary legislation, and therefore absolutely defenseless; because if it could, the right of freedom of contract would cease to live, and would become a mere plaything, and a license revocable at the will, whim or caprice of the lawmaking power; and therefore, the government would become a despotism, both in theory and in fact. Despotic power of this sort cannot live; for if it could, it would be destructive of the sacred right to enjoy and defend life and liberty, to acquire, possess and protect property, and to seek and obtain happiness and safety, solemnly declared to be inalienable by the Bill of Rights of the State of Ohio."101

Again, a statute was held to be an arbitrary interference with liberty and property and not within the legitimate sphere of legislation which released a city from paying for work performed under a contract because the contractor failed to pay the prescribed rate of wages to the workmen. ${ }^{102}$ The protection of the inalienable right of liberty of contract was taken up vigorously by the state courts and much labor legislation was thereby annulled; $;^{103}$ the protection in the Supreme Court culminated in the decisions of Lochner $v$. New York, ${ }^{10 \pi}$ Adair v. United States $^{105}$ and Coppage v. Kansas ${ }^{100}$ and led to the affirmation of the dictum of Justice Harlan that "the employer and the employee have equality of right, and any legislation that disturbs that equality is an arbitrary interference with the liberty of contract, which no government can legally justify in a free land. ${ }^{107}$

${ }^{101}$ State v. Norton, 5 Ohio N. P. R. 183 (1898).

${ }_{102}$ People ex rel. Rodgers v. Coler, 166 N. Y. I, I5 (I90I). Parker, Ch. J. (dissenting), "The reasoning by which the decision about to be made is sought to be supported fails to persuade me that it is other than a judicial encroachment upon legislative prerogative; for it is that and nothing less if the statute does not offend against either the Federal or the State Constitution," p. 25.

${ }^{203}$ For an excellent summary and discussion of cases consult Pound, Liberty of Contract, I8 Yale Law Journal, 454.

${ }^{104}$ Ig8 U. S. 45 (I904).

${ }^{100} 208$ U. S. I6I (1907).

${ }^{100} 236$ U. S. I (I914).

${ }^{107}$ Adair v. U. S., 208 U. S. I6I, I75. For a suggestive discussion of the development of liberty of contract as an outgrowth of natural law notions in reviewing labor legislations, consult Pound, Liberty of Contract, I8 Yale Law Journal, 454. 
In defining equal protection as well as due process it was declared that the very nature of the law is opposed to all merely arbitrary or capricious acts on the part of the state. Purely arbitrary acts of the legislature directed against individuals or classes of individuals are held not to conform to due process or the requirement of equal protection of the laws. ${ }^{108}$

"It is manifestly contrary to the first principles of civil liberty and natural justice," affirmed the Supreme Court of Massachusetts, "and to the spirit of our constitution and laws, that any one citizen should enjoy privileges and advantages, which are denied to all others under like circumstances: or that any one should be subjected to losses, damages, suits or actions, from which all others under like circumstances are exempted." 108 In rendering a judgment on a similar issue the Supreme Court of Vermont held that there is no such thing as absolute despotic power in our government. ${ }^{110}$ More recently Justice Talbot of Nevada, in deciding that the business of banking is a lawful business which it is the inherent right of every citizen to engage in, holds that the legislature may regulate when regulation will protect. ${ }^{111}$ Due process and equal protection are said to be secured within the meaning of the Fourteenth Amendment "if the laws operate on all alike, and do not subject the individual to an arbitrary exercise of the powers of government." ${ }^{112}$ It is only by the exercise of a power to invalidate legislation under these general restraints that courts are said to be enabled "to repel assaults and protect every part of the government and every member of

${ }^{200}$ McGehee, Due Process of Law, pp. 60, 6r.

${ }^{100}$ Holden v. James, II Mass. 396, 403 (18I4).

${ }^{110}$ Ward v. Barnard, I Aikens I20, I27, 128 (1825); for an interpretation of the "law of the land" as an inhibition against arbitrary acts, see, Vanzant v. Waddell, 2 Yerg. 260, 270 (183I) and Wally's Heirs v. Kennedy, 2 Yerg. 554; Bank of State v. Cooper, 2 Yerg. 599; Ex parte Dorsey, 7 Porter 293 ( 1838$)$; Barbour v. Louisville Board of Trade, $82 \mathrm{Ky} .645$ (I884).

111 Marymount v. State Banking Board, 33 Nev. 333, 34I (I9I0).

${ }^{112}$ Giozza v. Tiernan, I48 U. S. 657, 662 (1892); for the affirmance of liberty of contract as against legislative acts deemed by the courts as an arbitrary invasion of individual rights, see Braceville Coal Co. v. People, 35 N. E. 62 (1893); Frorer v. The People, I4I I1l. I7I (I892); also, Millet v. People, II7 IIl. 294 (I886); State v. Loonis, II5 Mo. 307, 3I7 (I892). In this case, Justice Barclay dissents with the observation: "It amounts in substance to a declaration that statutes which seem to the court unjust or unreasonable are not 'due process of law' though not otherwise distinctly forbidden by the constitution." 
the community from undue and destructive innovations upon their charter rights."113

The cases which involve judgments of a court without service or appearance in which natural law and justice is one of the grounds of the decision are comparatively rare. A few of the precedents, however, must be ranked foremost among the natural law decisions. In Harris v. Hardeman, relative to the lack of service either actual or constructive, the Supreme Court quoted the state courts to the effect that the necessity of service "does not depend merely upon adjudged cases. It has a better foundation, it rests upon a principle of natural justice."114 "If to hold a defendant bound by such a judgment (without service) is contrary to the first principles of justice" according to Justice Field "it is difficult to see how the judgment can legitimately have any force within the state." 115 The individual rights of person and property are accorded substantial protection through the inclusion of inalienable rights in due process. ${ }^{116}$

4. The Application of the Test of Reasonableness. One of the last but not the least significant developments of natural law is to be found in the application of the test of reasonableness to legislative acts, particularly with respect to the police power, to the regulation of corporate industry and public utilities. It has been a time-honored practice of courts to test the ordinances and by-laws of corporate bodies as well as the acts of subordinate government units, such as cities and counties, on the basis of reasonableness. The judiciary of the United States was prevailed upon to introduce this test as a part of the doctrine of the judicial review of legislation and to require the test of reasonableness for legislative acts, particularly with respect to the police power and to industrial legislation. Notice and hearing, the fundamental conditions of due process, according to Professor Freund, would be without value if it did not assure a just cause for proceeding against the individual; the essence of due process then is just cause, and this must underlie every act of legislation.

\footnotetext{
${ }^{113}$ State v. Goodwill, 33 W. Va. I79, I87 (I889).

114 Justice Daniel in I4 Howard 334, 34I (I852). See also, Scott v. McNeal, 154 U. S. 34 (I\&93); and Starbuck v. Murray, 5 Wendell 156 (I830).

${ }^{115}$ Pennoyer $v$. Neff, 95 U. S. 714, 732 (1877).

${ }^{110}$ Consult article by Shattuck, The True Meaning of the Term "Liberty" in those Clauses in the Federal and State Constitutions which protect "Life, Liberty and Property," 4 Harvard Law Review, 365.
} 
"The just cause of legislation," he maintains, "is the performance of some legitimate function of government. It thus becomes a requirement of the constitution that every statute should be the exercise of some recognized power justified by the reason and purpose of government." Each department of government has its inherent purpose or function based upon rules and limitations that are above legislation. It is for the courts in the United States to enforce these limitations. Professor Freund continues:-

"There has never been a civilized government which has not recognized, and practically acted upon, the existence of limitations of the nature here indicated. For all governments profess to apply or to make law, and the nature of law implies the idea of restraint according to intelligible principles of reason. The peculiarity of American jurisprudence and government lies in the possibility of subjecting legislation to judicial control with a view to enforcing these principles and limitations. In one view of the matter, it is still the government, and only a different department of it, which conclusively determines whether a given act is within the principle of reason or not. But the great determination is withdrawn from a body accustomed to follow considerations of expediency and interest, and vested in organs which by virtue of their constitution, methods of procedure, and traditions, are peculiarly qualified and apt to give effect to the claims of reason and justice." ${ }^{117}$

One of the earliest applications of the test of reasonableness with respect to the police power came in connection with regulations interfering in an incidental way with property rights. For the common good and general welfare courts were inclined to hold that rights of property, like all other social and conventional rights, were subject to reasonable limitations as well as reasonable restraints and regulations. ${ }^{118}$ If enactments "are repugnant

\footnotetext{
${ }^{117}$ Freund, Police Power, pp. 15, I6.

${ }^{118}$ Commonzuealth $v$. Alger, 6I Mass. 84 (I857); also Westerfelt $v$. Gregg, I2 N. Y. 202 ( 1854 ); Barbour v. Louisoille Board of Trade, $82 \mathrm{Ky}$. 645 (I884); J. Pryor dissented on the ground that "when a court of equity undertakes to deprive the legislature of the right to exercise its discretion as to what constitutes the public welfare it is an assumption of power that does not belong to the judicial tribunal of the state," p. 666. Says Justice Gilchrist, "What is the power of a state legislature in those particulars in which it is not limited by the constitution? Clearly it is supreme within its appropriate sphere. It
} 
to the natural sense of justice, subversive of the principles of sound legislation, and conflict with a wholesome policy long established and sanctioned by the tests of experience and common consent" as well as when they transcend the limits of the legislative authority as defined by the constitution they are to be declared null and void, says the Supreme Court of North Carolina. ${ }^{119}$

Every exercise of the police power it is held must be reasonable $;^{\mathbf{1 2 0}}$ whether it is a reasonable or an unreasonable exercise of legislative power over the subject matter involved is often a matter of fact, and in many cases questions of degree are the controlling ones. ${ }^{121}$ Although no express limitations on the police power are to be found in the constitution of Ohio, says Justice Davis, "such limitations as are recognized arise by construction from the nature of the power itself and the declaration of rights." ${ }^{22}$ When the courts declare a statute void on the ground that it is unreasonable, they necessarily assume the existence of a standard of reasonableness which is above legislative polity. ${ }^{123}$

It is impossible to go into the various ramifications of the application of the reasonable test to legislation under the police power. ${ }^{124}$ Not only is the reasonable test applied to regulations

may make all such laws as do not outrage the rights of person and property, upon a proper regard to which civilized society depends so much for its existence; and when we say that it cannot make a law thus obnoxious, we mean rather that society could not exist if such laws were passed, than that the constitution has in terms prohibited them." Concord Ry. Co. v. Greely, I7 N. H. 47, 54 (1845).

${ }^{11}$ Hoke v. Henderson, 4 Dev. (N. C.) I, 3 (I833).

${ }^{10}$ Yick $W_{0}$ v. Hopkins, II8 U. S. 356 (I885); Plessy v. Ferguson, I63 U. S. 537, 550 (I895).

${ }^{221}$ Cf. Wisconsin $M$. \& $P$. Ry. Co. v. Jacobson, I79 U. S. 287 (1900); Freund, pp. 57, 60 .

${ }^{122}$ Mirick v. Sims, 79 Ohio St. 174, I78 (Ig08).

${ }^{123}$ Freund, Police Power, p. 57: "The courts assume a general function of supervision regarding the adjustment of means to ends in the protection of public interests. While they profess to regard the state legislature as a coördinate power, they frankly treat the municipal authorities as subordinate. . . . As the power of judicial control over statutory legislation is more and more distinctly assumed, and the theory of the necessity of express limitations is abandoned, the adjudications on ordinances will become more valuable as precedents to indicate the measure of legislative power in the interest of health and safety." Freund, p. 132 .

${ }^{124}$ See especially, Freund, Police Power; for application of the test to protective legislation, see, Powell v. Penta., I27 U. S. 678, 685 
under the police power, but also to the regulation of public utility rates $^{125}$ and to the control of combinations and monopolies both by common law and by recent decisions under the Sherman Act, ${ }^{128}$ - an extensive and far reaching application of the test to which only passing reference is possible here. "Practically, the present system of judicial review means that the three departments of the government must be convinced of the justice and reasonableness of a change in social or economic policy before it can be enacted into law."127

The requirement of reasonableness as developed in connection with the growth of due process and equal protection under the Fourteenth Amendment must be regarded as one of the most potent of the restrictions upon legislative activity imposed by constitutions and the implied limitations of judicial cognizance. ${ }^{128}$ While it cannot be claimed that the extension of the common law doctrine of reasonableness is entirely a result from and an evolution of the mediaeval and eighteenth century idea of a law of nature it can nevertheless be readily seen that the earlier concepts of nature and reason form the basis and condition the development of this branch of constitutional limitations.

(1887); Holden v. Hardy, 169 U. S. 366, 391 (I897); McLean v. Arkansas, 2 II U. S. 539, 547 (1908); Chicago, Burlington \& Quincy R. R. v. McGuire, 219 U. S. 549, 569 (1900). Justice Hughes said: "The principle involved in these decisions is that where the legislative action is arbitrary and has no reasonable relation to a purpose which it is competent for government to effect, the legislature transcends the limits of its power," p. 569 .

${ }_{1=5}$ Chicago, Milwaukee \& St. Paul Ry. Co. v. Minnesota, 20 Wall. 669 (1874). "There can be no doubt of the power and duty of the courts to inquire whether a body of rates imposed by a legislature or a commission is unjust and unreasonable, and such as to work a practical destruction of righits of property, and if found so to be, to restrain its operation." Reagan v. Farmer's Loan and Trust Co., 154 U. S. 362 ; Int. Com. Comm. v. Union Pacific R. R. Co., 222 U. S. 54I (I9II).

${ }^{120}$ Northern Securities Co. v. U. S., 193 U. S. 197 (1903) ; Standard Oil Co. v. United States, 2 II U. S. I (I908); U. S. v. Anerican Tobacco Co., 2II U. S. ISg. Cf. also, dissenting opinion of Justice White, $U . S$. v. Freight Association, I66 U. S. 290 (I896) especially, p. 355.

${ }^{127}$ Freund, Police Power, p. I7.

${ }^{123}$ The influence of the law of reason in the development of equity and international law as well as in other branches of the law cannot be considered in this article although the evolution of the concept of reasonableness along these lines is no less interesting or significant than in those selected for treatment. 


\section{IV}

Among the terms in rather common usage in judicial opinions involving the application of natural law ideas are,-

\begin{tabular}{|c|c|c|}
\hline $\begin{array}{l}\text { just .......... unjust or discriminatory } \\
\text { appropriate.... inappropriate } \\
\text { reasonable.... unreasonable } \\
\text { convenient.... inconvenient }\end{array}$ & $\begin{array}{l}\text { Natural law } \\
\text { Natural reason } \\
\text { Natural justice } \\
\text { Natural equity }\end{array}$ & $\begin{array}{l}\text { equality } \\
\text { uniformity } \\
\text { common welfare } \\
\text { justice, equity } \\
\text { and good con- } \\
\text { science } \\
\text { public purpose } \\
\text { public welfare }\end{array}$ \\
\hline
\end{tabular}

All of these terms, used as grounds for the determination of the validity of statutes, are to a certain extent, at least, a development from the ancient and mediaeval concepts, law of nature and law of reason, and whether held to be a part of written constitutions or independent of the fundamental law they involve the use of the law of nature theory and philosophy in accordance with the methods and terminology peculiar to modern jurisprudence.

The disposition to deny the potency of the doctrine and to relegate all opinions relative thereto to the comparatively insignificant rôle of dicta fails to give due credit to the direct judgments of courts based on this principle, to the numerous dissenting opinions of judges recognizing the application of the principle in the majority opinion and judgment and to the development of due process and equal protection to include natural law and reasonableness in broad and varied applications. ${ }^{129}$

The law of nature as applied in American courts has been subjected to severe criticism. In the first place it is strenuously insisted upon in many quarters that it is entirely beyond the

${ }^{120}$ A partial explanation of the lack of sympathy with and appreciation of the influence of natural law may be accounted for in the impressions of the composite traits of a typical court as described by Dean Wigmore. (I) lack of acquaintance with legal science; (2) lack of acquaintance with legal history; and (3) the philosophy and jurisprudence of the law are unknown. The Qualities of Current Judicial Decisions, 9 Illinois Law Review, 527. What is characteristic of a typical court in this regard is even more characteristic of the average lawyer, and it may be presumed that lawyers and judges who have neither acquaintance with nor appreciation of legal science, legal history, and legal philosophy would not be likely to give much consideration to the law of nature. 
function of courts to deal with such a vague and indefinable concept. Judges and lawyers who are guilty even of incidental references to this idea are subjected to both ridicule and censure by the strict letter advocates of constitutional interpretation. The assumption that natural law is something absolute and unalterable which was a characteristic of the Middle Ages and was prevalent in the eighteenth century was followed by a theory of the historical and analytical schools of jurisprudence in England and America which aimed to recognize only positive law, thus attempting to rule out natural law entirely. ${ }^{130}$ These schools of jurisprudence have encouraged the theory that the very idea of the law rendered the notion of natural law impossible. They have fostered the practice now so common among the practical men of bench and bar to cast ridicule and scorn upon natural law as. well as upon jurisprudence and what is commonly known on the continent as the philosophy of law. But, as Sir Henry Maine demonstrated some years ago, ${ }^{131}$ the common lawyers are disposed to maintain a legal fiction although the practice contrary to the fiction is a well recognized fact to the members of the profession. Thus it is the vogue for the legal profession to deny the potency of natural law and natural rights at the same time that courts and judges are making free use of such notions in their opinions and judgments when on occasion it seems wise and appropriate.

A more recent charge is brought against the natural law adherents. This charge is to the effect that through judicial decisions an effort is made to enforce eighteenth century notions upon existing law and that modern social and industrial legislation must conform to an absolute and immutable standard of natural right or be annulled. Says Dean Pound, "Eighteenth century jurists conceived that certain principles were inherent in nature, were necessary results of human nature, and that these principles were discoverable $a$ priori. They held that it was the business of the jurist to discover these principles, and, when discovered, to deduce a system therefrom and test all actual rules thereby. Such is even now the orthodox method in our constitutional law. Our bills of rights are regarded as merely declaratory of fundamental natural rights. Eminent judges assert that legislation is to be judged by those rights and not by the constitutional texts

${ }^{23 s}$ Berolzheimer, World's Legal Philosophies, p. 6.

${ }^{10 r}$ Ancient Law, pp. 24, ff. 
in which they are declared." 132 It is claimed that the prevalence of the eighteenth century notions of natural law have tended to preserve the doctrine of laissez faire in government long after industrial conditions have rendered that theory obsolete and to foster an ultra individualism in an age when social conditions and thought demand socialization of the law. ${ }^{133}$ That this criticism is well founded is evident in the restrictions placed upon legislative action under the divisions, police power, labor regulations, control of public utilities, and attempted limitations of property and personal rights for the social welfare by such concepts as reasonableness, equal protection, implied limitations on legislative power, liberty of contract, and fundamental rights. Too frequently, indeed, courts, armed with a conception of natural and inalienable rights regarded as absolute and with express provisions of a general nature in constitutions, have acted on the theory that the affirmative powers of a government erected for the protection of a free people should be few and that the regulations and prohibitions should be many. ${ }^{134}$

At the same time that natural law is receiving judicial sanction in the United States the idea has been undergoing a revival in European countries. While natural law has always been rather significant in Europe, particularly in countries like France where the philosophic jurists are dominant, it has recently been accorded even greater significance. On the theory that positive law is regarded as the rules formulated by a lawmaker and sanctioned by an external authority, rational law is conceived as "rules which, in the eyes of reason, ought to be sanctioned by an external restraint." "135 The idea of natural law, according to a mod-

${ }_{132}$ Pound, Law in Books and Law in Action, 44 American Law Review, 28. See a criticism of the natural law of the practicing lawyer, examples of which abound in our judicial decisions, and the juristic theories have been more barren than the eighteenth century natural law of American judges in the nineteenth century, 24 Harvard Law Review, 609, 6II; Cf. also Borgnis v. Falk Co., I47 Wis. 327.

${ }^{133}$ Cf. Pound, Enforcement of Law, Proceedings of the Illinois State Bar Association, Igo8; also Puritanism and the Common Law, 45 American Law Review, 8ri.

${ }^{134} \mathrm{Cf}$. Dean, The Law of the Land, 48 American Law Review, 660. See, People v. Coler, I66 N. Y. I, I4, for the observation: "It is proper for courts to keep in mind in expounding the constitution the maxim that that government governs best which governs least."

${ }_{13}$ Boistel, Cours de philosophie du droit, secs. I, 2. Cf. Berolzheimer, p. 321 . 
ern exponent, is conceived differently from what it was formerly. "It is reconciled with the idea of evolution and with the idea of utility. It loses its absolute and immovable character. It has only a variable content. It takes account of the interdependence of the individual and the whole. It tends also to reconcile the individual conscience and the law."136 This new natural law sanctions only such laws as are theoretically just under existing conditions. It beçomes, as has been aptly termed, "a natural law with a variable content."137

The old natural law was assumed to be made up of principles to which the positive law must of necessity conform. The new natural law results in a search for a body of rules governing legal development in accordance with the prevailing economic, social and political conditions. To the sociological jurist who regards legal rules merely as a general guide to the judge and who insists that the judge should be free to deal with individual cases in such a way as to meet the demand of justice between the parties the law of nature and of reason becomes important. Under the influence of both the philosophical and sociological jurists it appears destined to an even more eventful career than in the past. ${ }^{138}$

The quest of jurists and judges for principles of justice, to which they seek to make the rules enforced in tribunals approximate so far as possible, is manifestly one of the determining influences in the evolution of law as well as in its modern appli-

${ }^{123}$ Charmont, La renaissance du droit naturel, I22-127. Pound, Scope and Purpose of Sociological Jurisprudence, 25 Harvard Law Review, 492. On the distinction between the old natural law philosophy and the modern philosophy of the law, cf., Berolzheimer, System der Rechts und Wirtschaftsphilosophie II, Sec. 4, Rechtsphilosophie und Naturrecht.

${ }^{137}$ Berolzheimer, Intr., p. xiv, quoting Stammler, Die Lehre von dem Richtigen Rechte, p. I37.

${ }^{123}$ Pound, 25 Harvard Law Review, 515: "It is not an accident," says Dean Pound, "that something like a resurrection of natural law is going on the world over," 25 Harvard Law Review, 162. For sanction of the principle that when judges do not find the rules of law sufficient for the settlement of controversy they may decide "according to the principles of natural law" consult Austrian Civil Code, Int. Secs. 6-8 and Italian Civil Code, Sec. 3. A similar practice to the effect that judges may be guided by the "rules of equity which exist in the maxims of natural law, universal justice and reason" seems to be sanctioned by the interpretation placed upon Article 5, of the French Civil Code, and the general functions of the judge as commonly understood in France. 
cation in Europe and America. The great characteristic of the principles of civil and criminal justice is acknowledged to be that they do not appear as the dictates of government, but as the dictates of reason. ${ }^{139}$ Natural law is, to be sure, nothing more than the individual judge's or jurist's conception of what ought to be law, and often it involves preconceived notions of right and justice to which positive laws are made to conform. ${ }^{\mathbf{1 4 0}}$ The law of nature has been styled an "appeal from Caesar. to a better informed Caesar," and as an appeal by society at large, or by the best spirits of a given society, against single decisions or against the entire system of positive law. ${ }^{141}$ As an application of individual judge's and jurist's ideas of right and morality in advance of those which have been enacted into formal positive law, it cannot but be a leavening process in any legal system. When the adjustment of formal law to meet new conditions of ethics and morality is peculiarly difficult, it is all the more necessary to grant the judges the privilege of following rules of nature and reason so as to accord substantial justice even though not always in harmony with the strict letter of the law.

If the contention be true that law in its essence is nothing more nor less than reason and common sense as applied to human relations, and if, as is generally conceded, the enactments of positive law and judicial decisions, crystallized into formal precedents, lag behind man's development along moral, social and economic lines, then it is very necessary indeed that the judges be accorded the privilege of applying the saving grace of reason, under whatever cloak, to square the law with the more advanced precepts of morality, ethics and justice. In the United States, where analytical jurisprudence is powerful, where statutory law is voluminous and where judicial decisions are followed as binding precedents, it is preëminently necessary that the doctrine of reason find acceptance and ready application in order that law may be speedily adjusted to meet the rapidly developing social and industrial needs. To be sure, the legislature is the body that is primarily expected to make such adjustments and the courts

\footnotetext{
${ }^{130}$ Freund, Police Power, p. 5.

${ }^{140}$ Natural right is "an ambiguous way of saying what might be less ambiguously expressed by a direct use of the term 'ought," Ritchie, Natural Rights, p. 75 .

${ }^{111}$ Cf. Vinogradoff, Common Sense in Law, Chap. IX, The Law of Nature.
} 
can do nothing more than fill the gaps and guide the legislative process. In the guiding process whereby the old law of nature of the past has been absorbed in due process it is certain that the courts will take a prominent part in directing the development of the law. It is also evident that if nature and reason are to be used as standards to judge many varieties of legislation, it cannot continue to be an absolute standard based on eternal and immutable principles of any past age which are held as barriers to the beneficence and wisdom of the legislature in an effort to ameliorate social wrongs, but will rather become a nature and reason with changing content, varying in significance and scope to meet the rapid modifications in political, social and industrial affairs and designed to render more equitable and just the application to concrete cases of the formal provisions of statutes and constitutions.

Charies Grove Haines.

UNIVERSITY OF TEXAS. 